\title{
Comparisons Of Labour Productivity And Per Capita Income In The Nordic Countries (2000-2010)
}

Gorm Jacobsen, University of Agder, Norway

\begin{abstract}
Due to increased international trade for the last decades and also increased labour and capital mobility, there has been increased interest in international comparisons of economic performance and living standard among countries. Economic performance for a country may be measured by average labour productivity while living standard is measured by production per capita. Differences in these figures among countries are determined by differences in the number of working hours per person per year and the share of the population that works. This approach gives us the opportunity to examine how living standard and economic performance are related.

Labour productivity depends, in general, on the amount of labour and capital, but also on factors like the education of the labour force and in investments in more modern technical equipment. This study will give us some ideas of the relative importance of labour market policy and the necessity for investments to improve the economic conditions in a country.
\end{abstract}

Keywords: Growth; Income Per Head; Labour Productivity

\section{INTRODUCTION}

C n this work, we measure the economic performance of the Nordic countries - Denmark, Finland, Iceland, Norway and Sweden - over the period 2000 to 2010. Differences in economic performance and in living standard measured by average labour productivity and income (Gross Domestic Product - GDP) per capita, respectively, are determined by differences in the number of annual working hours per person and the share of the population that work. In this analysis, we measure each country's labour productivity and income per head against the average for the whole group. The theoretical framework used in this study utilizes three modeling techniques for calculating income per head and labor productivity. In this way, we obtain the necessary values to measure the comparative gaps in labor productivity and labour utilization between these countries. In this way, we can find out whether economic weaknesses are more attributed to lack of capital or labour market instability, respectively.

The first part of this article gives a theoretical framework and an overview of the models to be applied in this work. By calculating labour productivity and the number of hours per capita, we calculate income per head in each country. The analysis of these results focuses on income per head and labour productivity for the years 2000 to 2010. This allows us to study the change in output over time, including some of the effects of the financial crises in 2008 .

\section{THEORETICAL FRAMEWORK - THE MODEL}

The first equation used in our analysis is as follows:

(1) $\left(\frac{O}{P}\right)^{X}=\left(\frac{O}{H}\right)^{X}\left(\frac{H}{P}\right)^{X}$ 
The multiplication of labour productivity $(\mathrm{O} / \mathrm{H})$ by the number of hours worked per capita $(\mathrm{H} / \mathrm{P})$ gives us the value of output per head $(\mathrm{O} / \mathrm{P})$ in country $\mathrm{x}$. This equation shows the relationship between Gross Domestic Product; i.e., output $(\mathrm{O})$ per capita $(\mathrm{P})$ in a country and labour productivity per hour $(\mathrm{O} / \mathrm{H})$ multiplied by hour worked per capita (H/P) during the year. Labour productivity, as well as total output, depends, among others, on investment in both physical and human capital in each country and also of the organization of the economy. Differences in the GDP per capita can then be traced to differences in labour productivity and to differences in hours worked per head. Countries with less capital intensive production will normally obtain lower levels of labour productivity.

The calculation based on equation (1) gives us an indication of the level of the capital/labor ratio for each country. This equation enables us to identify the sources of labour productivity as well as each country's relative success in tackling labour market weaknesses.

The second equation in our analysis is as follows:

$$
\text { (2) } \mathrm{x}_{1}=\frac{\left(\frac{O}{H}\right)^{x}}{\left(\frac{O}{H}\right)^{y}} \cdot 100
$$

This equation measures the relative value in percentage terms of a given country's labour productivity $(\mathrm{O} / \mathrm{H})^{\mathrm{x}}$ in relation to the Nordic countries' average $(\mathrm{O} / \mathrm{H})^{\mathrm{y}}$. Increases in the average labour productivity can be achieved via investment in physical capital and increased total factor productivity.

Equation (2a) calculates the actual labour productivity gap (LPG) between each of the individual countries and the average of all countries:

(2a) $\quad \mathrm{LPG}^{\mathrm{x}-\mathrm{y}}=\mathrm{x}_{1}-100$

Countries with a positive labour productivity gap have greater labour productivity than the average of the whole group of countries, and vice versa for countries with lower labour productivity.

The third equation is as follows:

(3) $\quad \mathrm{LU}^{\mathrm{x}-\mathrm{y}}=\mathrm{x}_{2}=\frac{\left(\frac{O}{P}\right)^{x}}{\left(\frac{O}{P}\right)^{y}} \cdot 100$

This equation measures GDP per person $(\mathrm{O} / \mathrm{P})^{\mathrm{x}}$ in one country relative to the average of all countries. We call this labour utilization (LU). Output per head depends, among others, on each country's utilization of the labour force and on how big a part of the population is part of the labour force. Higher level of employment and higher share of the population in the working force increase GDP per capita. The unemployment rate depends on macroeconomic conditions in each country such as the possibility for fiscal and monetary policy. It also depends on the efficiency of public and private labour market policy. Numerous other factors like real wages, health conditions and unemployment benefits also influence the unemployment rate in each country.

Equation (3a) measures the actual labour utilization gap $\left(\mathrm{LUG}^{\mathrm{x}-\mathrm{y}}\right)$.

(3a) $L U G^{x-y}=x_{2}-x_{1}$

This is determined by subtracting the relative value of labour productivity from the relative value of output per head. 


\section{Equation (1) - Results}

By using formula (1), we obtain the results presented in Table 1a.

(1) $\left(\frac{O}{P}\right)^{x}=\left(\frac{O}{H}\right)^{x}\left(\frac{H}{P}\right)^{x}$

Table 1a: Labour Productivity (USD), Hours Per Head \& Income Per Head (USD) And Ranking

\begin{tabular}{|l|c|c|c|c|}
\hline \multicolumn{1}{|c|}{ Country } & $\begin{array}{c}\text { Labour Productivity } \\
(\mathbf{O} / \mathbf{H})\end{array}$ & $\begin{array}{c}\text { Hours Per Head } \\
(\mathbf{H} / \mathbf{P})\end{array}$ & $\begin{array}{c}\text { Income Per Head } \\
(\mathbf{O} / \mathbf{P})\end{array}$ & $\begin{array}{c}\text { Rank Income Per Head } \\
(\mathbf{O} / \mathbf{P})\end{array}$ \\
\hline Denmark 2000 & 28.50 & 806 & 22971 & 2 \\
\hline Finland 2000 & 25.68 & 777 & 19953 & 6 \\
\hline Iceland 2000 & 20.05 & 1049 & 21032 & 1 \\
\hline Norway 2000 & 33.39 & 751 & 25076 & 5 \\
\hline Sweden 2000 & 26.38 & 791 & 20867 & 5 \\
\hline & & & & 23679 \\
\hline Denmark 2010 & 30.28 & 782 & 23455 & 4 \\
\hline Finland 2010 & 30.07 & 780 & 23826 & 1 \\
\hline Iceland 2010 & 25.73 & 926 & 28076 & 2 \\
\hline Norway 2010 & 35.72 & 786 & 25134 & \\
\hline Sweden 2010 & 31.03 & 810 & & 21980 \\
\hline
\end{tabular}

Source: Groningen database.

Table 1b: Percent Change In Labour Productivity And Hours \& Income Per Head (2000-2010)

\begin{tabular}{|l|c|c|c|}
\hline \multicolumn{1}{|c|}{ Country } & Labour Productivity (O/H) & Hours Per Person (H/P) & Output Per Head (O/P) \\
\hline Denmark & 6.2 & -3.0 & 3.1 \\
\hline Finland & 17.1 & 0.4 & 17.6 \\
\hline Iceland & 28.3 & -11.7 & 13.3 \\
\hline Norway & 7.0 & 4.7 & 12.0 \\
\hline Sweden & 17.6 & 2.4 & 20.4 \\
\hline & & & 13.0 \\
\hline Nordic average & 14.1 & -2.2 & \\
\hline
\end{tabular}

Source: Groningen database

Measured in Purchasing Power Parity (PPP), Norway is ranked first when it comes to output per capita in both 2000 and 2010 with USD 25,076 and USD 28,076 measured in 1990 prices. Except for Denmark, all other Nordic countries have a stronger growth rate in GDP per capita than Norway during this period.

From the figures, we see that Finland, Iceland and Sweden have a significantly stronger increase in labour productivity compared to Norway, which explains why they are catching up with Norway when it comes to income per head, since hour per head worked has increased most in Norway during this ten-year period.

Except for Denmark and Sweden, which have changed ranking from $2^{\text {nd }}$ to $5^{\text {th }}$ place when it comes to income per head, the other countries ranking, as well as the Nordic average $\left(3^{\text {th }}\right)$, remained the same in 2000 and 2010 .

The characteristics for the two countries ranked above the Nordic average - Norway and Denmark in 2000 and Norway and Sweden in 2010 - are that they have a higher labour productivity than the Nordic average. The only country which has longer working hours than the average; i.e., Iceland still has a lower labor productivity and lower GDP per capita. This may be due to a small scale economy in some sectors of the economy due to a small population. An additional explanation may be that Iceland has one dominant sector in the economy; namely, the fishery sector. 
To get a clearer picture of our findings, Figure 1 shows relative income per head and labour productivity in the Nordic countries compared with the Nordic average in 2010.

\begin{tabular}{|c|c|}
\hline & $\mathrm{O} / \mathrm{P}$ \\
\hline 95.3 & (Denmark) \\
\hline 94.4 & (Finland) \\
\hline 95.9 & (Iceland) \\
\hline 113.1 & \begin{tabular}{l|l} 
(Norway) \\
\end{tabular} \\
\hline 101.2 & (Sweden) \\
\hline & $\mathrm{O} / \mathrm{H}$ \\
\hline 99.1 & (Denmark) \\
\hline 98.4 & (Finland) \\
\hline 84.2 & (Iceland \\
\hline 116.8 & (Norway) \\
\hline 101.5 & (Sweden) \\
\hline
\end{tabular}

Figure 1: Relative Income Per Head And Relative Labour Productivity In The Nordic Countries Compared With The Nordic Average In 2010

Source: Groningen database

By setting the Nordic average equal to 100, the upper and lower level of Figure 1 shows the relative value of income per head and of labour productivity, respectively.

As we see, Norway achieved 13.1 percent and 16.8 percent more than the Nordic average for income per head and labour productivity, respectively. The corresponding numbers for second place Sweden are 1.2 percent and 1.5 percent. This shows that labour productivity in Sweden generates almost a proportionate level of income per head, whereas it is less than proportionate in Norway. Measured in this way, we can conclude that Norway is less efficient than Sweden.

By comparing labour productivity with income per head, it is clear from the figures in Figure 1 that Iceland is the most efficient country among the Nordic countries measured in this way.

As for Norway, both Finland's and Denmark's labour productivity generates less than a proportionate level of income per head relative to Nordic average. Even if there are small differences for both variables for these three countries, it indicates that policy changes are required to improve efficiency in these countries. However, the differences in the figures for each country are relatively small.

\section{Equation (2) - Results}

From the model presentation we had relation (2):

(2) $\mathrm{x}_{1}=\frac{\left(\frac{O}{H}\right)^{x}}{\left(\frac{O}{H}\right)^{y}} \cdot 100$

measuring the relative value in percentage terms of a given country's labour productivity in relation to all countries average. Countries with values above 100 are those that benefit greater from investments in physical and human capital and/or increased working hours. On the other hand, values below 100 indicate countries in need of increased investments in physical capital and increased total factor productivity, including improved labor market policies. 
Another way of showing the same result is by using relation (2a) to calculate the labor productivity gap. When $\mathrm{x}_{1}$ for a country is above 100 , the LPG is positive, while countries with $\mathrm{x}_{1}$ less than 100 have negative LPG.

(2a) $\mathrm{LPG}^{\mathrm{x}-\mathrm{y}}=\mathrm{x}_{1}-100$

The results are presented in Table 2, together with labour productivity and relative labour productivity.

Table 2: Labour \& Relative Labour Productivity And Labor Productivity Gap (2000 \& 2010)

\begin{tabular}{|l|c|c|c|}
\hline \multicolumn{1}{|c|}{ Country } & Labour Productivity $(\mathbf{O} / \mathbf{H})$ & $\begin{array}{c}\text { Relative Labour } \\
\text { Productivity }\left(\mathbf{X}_{\mathbf{1}}\right)\end{array}$ & $\begin{array}{c}\text { Labour Productivity Gap } \\
\left(\mathbf{X}_{\mathbf{1}}-\mathbf{1 0 0}\right)\end{array}$ \\
\hline Year 2000 & & & 6.3 \\
\hline Denmark & 28.50 & 106.3 & -4.2 \\
\hline Finland & 25.68 & 95.8 & -25.2 \\
\hline Iceland & 20.05 & 74.8 & -1.6 \\
\hline Norway & 33.39 & 124.6 & 0 \\
\hline Sweden & 26.38 & 98.4 & \\
\hline & & & -0.9 \\
\hline Nordic average & 26.80 & 100.0 & -1.6 \\
\hline & & & -15.8 \\
\hline Year 2010 & & & 16.8 \\
\hline Denmark & 30.28 & 99.1 & 1.5 \\
\hline Finland & 30.07 & 98.4 & 0 \\
\hline Iceland & 25.73 & 84.2 & 0 \\
\hline Norway & 35.72 & 116.8 & \\
\hline Sweden & 31.03 & 101.5 & \\
\hline & & & \\
\hline Nordic average & 30.57 & 100.0 & \\
\hline Soure: Gring
\end{tabular}

Source: Groningen database

In 2000, Finland (-4.2), Iceland (-25.2) and Sweden (-1.6) had a negative labour productivity gap. The values for Finland and Sweden show the need for greater investment and/or improved labor market conditions in order to bring it in line with the overall average. The case for Iceland (-25.2) is more severe and is consistent with a low capital labour ratio; therefore, it is in need of high investments. In contrast, Norway (24.6) has achieved values consistent with higher levels of investments, while Denmark was around 6 percent above average.

From the results for 2010, we see that Norway still has a positive labour productivity gap. This may be due to the fact that the Norwegian economy, to a great extent, is based on the extraction of oil and gas and therefore is a very capital intensive economy. Sweden has moved from a negative to a positive labour productivity gap, while Denmark has moved in the opposite direction during the same period. The case for Denmark may be the result of the recession in the European economy after the financial crisis in 2008 and the fact that the Danish krone is pegged to the Euro. Like Denmark, Sweden is also a member of the EU, but they have their own inflation target (flexible exchange rate). They have, therefore, the possibility to decide their own monetary policy to improve their internal economy. The development for both Finland and Iceland has resulted in a smaller labour productivity gap during this period. For Iceland, this may be due to huge investments until the financial crisis hit the country in 2008 .

\section{Equation (3) - Results}

Equation (3) is discussed in detail earlier in this article. This equation gives an indication of the conditions in the labour market in country $\mathrm{x}$ compared to the average situation in all the other countries.

(3) $\mathrm{LU}^{\mathrm{x}-\mathrm{y}}=\mathrm{x}_{2}=\frac{\left(\frac{O}{p}\right)^{x}}{\left(\frac{O}{p}\right)^{y}} \cdot 100$ 
By subtracting relative labor productivity $\left(\mathrm{x}_{1}\right)$ from relative labor utilization $\left(\mathrm{x}_{2}\right)$, we obtain the labour productivity gap (see $3 \mathrm{a}$ ). The results are presented in Table 3.

(3a) $L G^{x-y}=x_{2}-x_{1}$

Table 3: Income Per Head, Labour Utilization, Labour And Relative Labour Productivity And Labour Utilization Gap

\begin{tabular}{|c|c|c|c|c|c|}
\hline Country & $\begin{array}{l}\text { Income Per } \\
\text { Head }(\mathrm{O} / \mathrm{P})\end{array}$ & $\begin{array}{c}\text { Labour } \\
\text { Utilization }\left(\mathbf{X}_{2}\right)\end{array}$ & $\begin{array}{c}\text { Labour } \\
\text { Productivity } \\
(\mathrm{O} / \mathrm{H})\end{array}$ & $\begin{array}{l}\text { Relative Labour } \\
\text { Productivity }\left(\mathbf{X}_{1}\right)\end{array}$ & $\begin{array}{c}\text { Labour } \\
\text { Utilization Gap } \\
\left(\mathbf{X}_{\mathbf{2}}-\mathbf{X}_{1}\right)\end{array}$ \\
\hline \multicolumn{6}{|l|}{ Year 2000} \\
\hline Denmark & 22971 & 104.5 & 28.50 & 106.3 & -1.8 \\
\hline Finland & 19953 & 90.8 & 25.68 & 95.8 & -5.0 \\
\hline Iceland & 21032 & 95.7 & 20.05 & 74.8 & 20.9 \\
\hline Norway & 25076 & 114.1 & 33.39 & 124.6 & -10.5 \\
\hline Sweden & 20867 & 94.9 & 26.38 & 98.4 & -3.5 \\
\hline Nordic Average & 21980 & 100.0 & 26.80 & 100.0 & 0 \\
\hline \multicolumn{6}{|l|}{ Year 2010} \\
\hline Denmark & 23679 & 95.3 & 30.28 & 99.1 & -3.8 \\
\hline Finland & 23455 & 94.4 & 30.07 & 98.4 & -4.0 \\
\hline Iceland & 23826 & 95.9 & 25.73 & 84.2 & 11.7 \\
\hline Norway & 28076 & 113.1 & 35.72 & 116.8 & -3.7 \\
\hline Sweden & 25134 & 101.2 & 31.03 & 101.5 & -0.3 \\
\hline Nordic Average & 24834 & 100.0 & 30.57 & 100.0 & 0 \\
\hline
\end{tabular}

Source: Groningen database.

The figures show us that Norway is ranked first with respect to labour utilization, both in 2000 and 2010, with 14.1 and 13.3 above the Nordic average, respectively. The labour utilization gap has changed from -10.5 percent to -3.7 percent during this period. Most of the changes are explained by the reduction in relative labour productivity. This may be due to the fact that Norway has among the greatest active labour force in the world. There are also a great number of foreign workers in Norway, especially in the construction and service sectors. This may result in low marginal productivity of labour compared to other countries.

For Iceland, the situation is quite opposite than for Norway. The labour utilization gap for this country has changed from 20.9 percent in 2000 to 11.7 percent ten years later. All changes are a result of increased relative labour productivity. This indicates a good performance of labour productivity due to a high level of investments, especially until the financial crisis in 2008 .

In 2000, Denmark also had a labour utilization above average by 4.5 percent, but dropped below average in 2010 by -4.7 percent. For Sweden, the situation was opposite by -5.1 percent and 1.2 percent for the two respective years. This is a result of a significant increase in labour productivity during this period which may be a result of increased investments among others. During the same period, Denmark experienced a reduction in hours worked per persons which indicates problems in the labour market.

For Finland and Iceland, we see that both $\mathrm{x}_{1}$ and $\mathrm{x}_{2}$ are more in line with the Nordic average in 2010 compared to 2000. For Finland, the changes are much closer to the Nordic average, while for Iceland the labour utilization is almost unchanged while $\mathrm{x}_{1}$ are much closer to the average for the Nordic countries. As mentioned earlier, this may be due to a huge gross fixed capital formation until the beginning of the crisis in the banking sector in the country. From table (1b) we see that like Sweden these two countries had huge increases in labour productivity during the same period. 
Both the labour productivity gap and the labour utilization gap for 2010 are illustrated in Figure 2. By setting the Nordic average equal to zero, this graph gives a good image of labour productivity and labour utilization in each country compared to the average of all countries. This may be useful for policy decisions makers when it comes to decisions of a more efficient use of capital and labour.

Both Denmark and Finland are performing below the Nordic average when it comes to both the LPG and the LUG, but most to the LUG. To perform better on labour utilization, an active labour market policy will increase labour productivity.

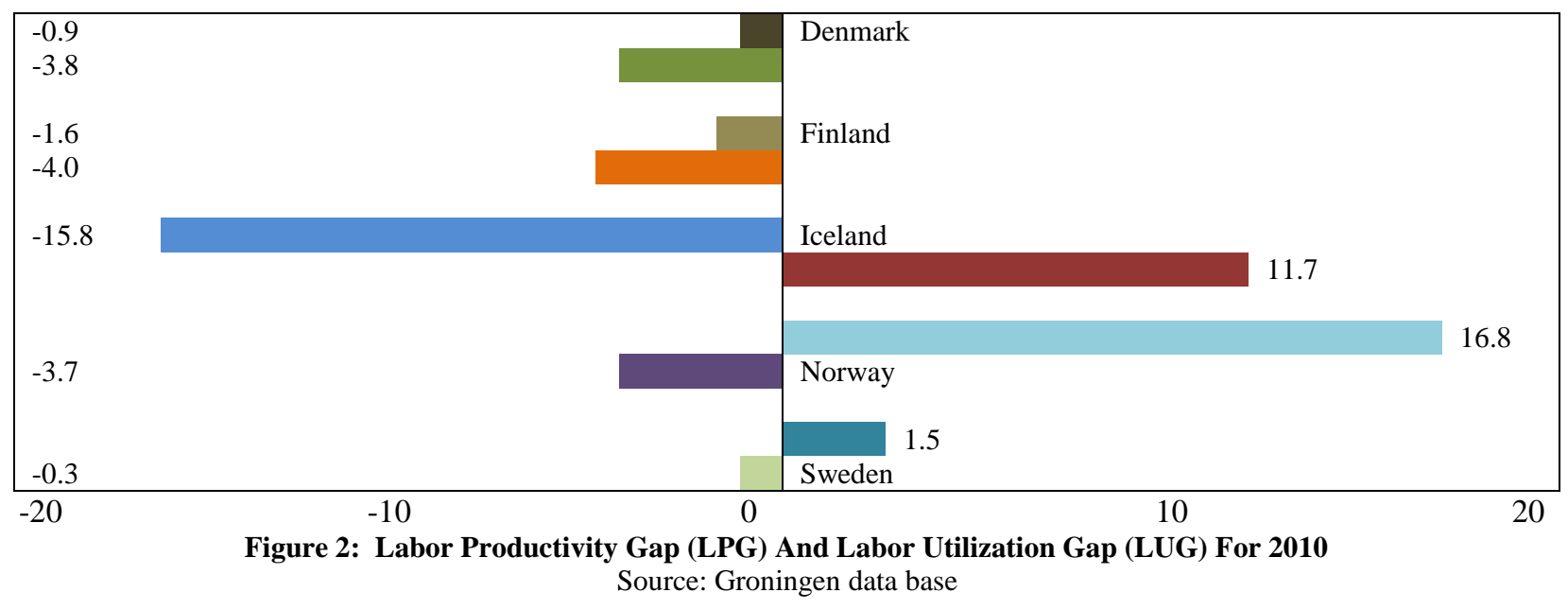

When it comes to Iceland and Norway, they have opposite positions due to the LPG and the LUG. Iceland has huge negative LPG and positive LUG, while the situation is opposite for Norway. For Iceland, it suggests that they are in need of investments to increase labour productivity. On the other side, Norway should try to use the labour force more efficiently.

For Sweden there are only small deviations from the Nordic average on both the LPG and the LUG.

\section{CONCLUDING REMARKS}

By the modeling technique used in this article, we identify necessary macroeconomic policy decisions which may improve the economy of all these countries.

Norway is still the most productive country measured by income per head and by labour productivity. By using the labour utilization gap (LUG) figures, Denmark, Finland and Norway have almost the same situation (see Figure 2), indicating the need for a more active labour market policy. For Norway, the welfare and pension benefits may be the ones to be changed to get people to stay longer in the labour market. In Iceland, the situation is somewhat opposite; people are working longer hours and the macroeconomic policy should still focus on more investments after recovering from the financial crisis at the end of the decade.

\section{AUTHOR INFORMATION}

Gorm Jacobsen has a bachleor's degree in business administration from University of Lund in Sweden (1977) and a master's degree in economics from University of Oslo in Norway (1986). Current position is Associate Professor of economics at Department of Working Life and Innovation, Faculty of Economics and Social Sciences at University of Agder in Norway. E-mail: gorm.jacobsen@uia.no 


\section{REFERENCES}

1. Ark, van B. \& McGuckin R.H. (1999): International Comparisons in Labour Productivity \& per capita income; Monthly Labor Review.

2. Baldwin, R., et al, (2004): Catching up and falling behind: The performance of provincial GDP per capita from 1990 to 2003; Statistics Canada.

3. Clowes D. \& Choros - Mrozowska D. (2012): Changes in labour productivity - measurements \& interpretations from Central - Eastern Europe; Cracow University of Economics.

4. Burda M. \& Wyplosz C. (2001): Macroeconomics (3.eds.); Oxford University Press.

5. Groningen Database; The Groningen Growth \& Development Centre, www.ggdc.net 